\title{
Maternal Hypothyroidism and Developing Hearing Loss
}

\author{
Ahmed R.G* \\ Division of Anatomy and Embryology, Zoology Department, Faculty of Science, Beni-Suef University, Beni- \\ Suef, Egypt
}

*Corresponding Author: Ahmed R.G, Division of Anatomy and Embryology, Zoology Department, Faculty of Science, Beni-Suef University, Beni-Suef, Egypt, Email: ahmedragab08@gmail.com

\section{SHORT COMMUNICATION}

The availability of gestational thyroid hormones (THs) is significant for the development of fetus and neonates (El-bakry et al., 2010; Ahmed, 2011, 2012a,b, 2013, 2014, 2015a-c, 2016a-d, 2017a-v, 2018a-r; Ahmed and Ahmed, 2012; Ahmed et al., 2008; 2010; 2012; 2013a,b, 2014, 2015a,b, 2018a,b; Ahmed and Incerpi, 2013; Van Hercket al., 2013; Ahmed and ElGareib, 2014,Incerpi et al., 2014; Candelotti et al., 2015; De Vito et al., 2015; El-Ghareeb et al., 2016; Ahmed and El-Gareib, 2017), in particular the morphogenesis and development of auditory system (the inner and middle ear) (Crofton, 2004; Wasserman et al., 2008 \& 2012; Dayal et al., 2016; Over cash et al., 2016; Oliveira de Andrade et al., 2017).Also, Cordas et al. (2012) reported that thyroid hormone receptors (TRs; $\alpha$ and $\beta$ ) can regulate the size of the ossicular bones, and the development and maturation of the middle ear. In addition, other factors such as Pax 2 and Pax 8 can share in the morphogenesis and innervation of the inner ear (Bouchard et al., 2010).Central auditory processes are responsible for auditory discrimination, localization/lateralization, auditory pattern recognition, and performance with competing or degraded acoustic signals (Bellis, 2003).

On the other hand, deficiency in the levels of thyroxine (T4) and 3,5,3'-triiodothyronine (T3), congenital or acquired hypothyroidism, can disrupt the central auditory pathway and the activity of cochlea(sensorineural hearing loss) (Musiek and Gollegly, 1985; $\mathrm{Ng}$ et al., 2004;Knipper, 2000; Crofton, 2004; Santos, et al. 2010;Dayal and Prasad, 2015; Prabhuet al., 2015; Dayal et al., 2016).Before the onset of hearing process, any deficiency in THs levels can cause permanent damage to peripheral and central auditory systems (Knipper et al.,
2000).Moreover, Weber et al. (2013) recorded that the genetic disorders in hydrogen peroxide $\left(\mathrm{H}_{2} \mathrm{O}_{2}\right)$ generation in the thyroid gland can interrupt the hearing process. Group of Wasserman et al. (2008 \& 2012) reported that the elevation in the concentration of autoantibody thyroid peroxidase (TPOaAb) during the third trimester of pregnancy was noteworthy and considerably connected to the neonatal sensorineural hearing loss (SNHL). Furthermore, maternal iodine exposure can increase the prevalence of the fetal goiter and neonatal hearing loss (Over cash et al., 2016).More importantly, even mild hearing loss in children may increase the risk of learning impairments, delayed speech and other overt or subtle developmental disorders (Smith et al., 2005; Bailey, 2010). This can be attributed to insufficient maternal free $\mathrm{T} 4$ during the early pregnancy (hypothyroid state). In both maternal hypothyroidism and hyperthyroidism states, the frequencies of neonatal hearing dysplasia were meaningfully increased (Su et al., 2011).

Thus, it is also worth declaring that THs and their receptors can regulate the development and functioning of auditory system. In addition, any dysfunctions in the activities of THs during the development may cause hearing loss. These disorders may delay the developmental cognitive behaviors and neonatal responses, cause numerous lifelong consequences and severely impact qualityof-life. The prevention with early detection and treatment of hearing loss may be amenable. Yearly audio logical evaluation to monitor hearing should be done. The results may be depending the age of hearing examination, the methods of hearing assessment, and the genetic factors in different patient populations. Further studies are required to determine the exact prevalence of hearing impairment in children with permanent congenital hypothyroidism. 


\section{REFERENCES}

[1] Ahmed, O.M., Abd El-Tawab, S.M., Ahmed, R.G., 2010. Effects of experimentally induced maternal hypothyroidism and hyperthyroidism on the development of rat offspring: I- The development of the thyroid hormonesneurotransmitters and adenosinergic system interactions. Int. J. Dev. Neurosci. 28, 437-454.

[2] Ahmed, O.M., Ahmed, R.G., 2012. Hypothyroidism. In A New Look At Hypothyroidism. Dr. D. Springer (Ed.), ISBN: 978953-51-0020-1), In Tech Open Access Publisher, Chapter 1, pp. 1-20.

[3] Ahmed, O.M., Ahmed, R.G., El-Gareib, A.W., El-Bakry, A.M., Abd El-Tawaba, S.M., 2012. Effects of experimentally induced maternal hypothyroidism and hyperthyroidism on the development of rat offspring: II-The developmental pattern of neurons in relation to oxidative stress and antioxidant defense system. Int. J. Dev. Neurosci. 30, 517-537.

[4] Ahmed, O.M., El-Gareib, A.W., El-bakry, A.M., Abd El-Tawab, S.M., Ahmed, R.G., 2008. Thyroid hormones states and brain development interactions. Int. J. Dev. Neurosci. 26(2), 147-209. Review.

[5] Ahmed, R.G., 2011. Perinatal 2, 3, 7, 8tetrachlorodibenzo-p-dioxin exposure alters developmental neuroendocrine system. Food Chem. Toxicology, 49, 1276-1284.

[6] Ahmed, R.G., 2012a. Maternal-newborn thyroid dysfunction. In the Developmental Neuroendocrinology, pp. 1-369. Ed R.G. Ahmed. Germany: LAP LAMBERT Academic Publishing GmbH \& Co KG.

[7] Ahmed, R.G., 2012b. Maternal-fetal thyroid interactions, Thyroid Hormone, Dr. N.K. Agrawal (Ed.), ISBN: 978-953-51-0678-4, In Tech Open Access Publisher, Chapter 5, pp. 125-156.

[8] Ahmed, R.G., 2013. Early weaning PCB 95 exposure alters the neonatal endocrine system: thyroid adipokine dysfunction. J. Endocrinol. 219 (3), 205-215.

[9] Ahmed, R.G., 2014. Editorial: Do PCBs modify the thyroid-adipokine axis during development? Annals Thyroid Res. 1(1), 11-12.

[10] Ahmed, R.G., 2015a. Chapter 1: Hypothyroidism and brain development. In advances in hypothyroidism treatment. Avid Science Borsigstr.9, 10115 Berlin, Berlin, Germany. Avid Science Publications level 6, Melange Towers, Wing a, Hitec City, Hyderabad, Telangana, India. pp. 1-40.

[11] Ahmed, R.G., 2015b. Hypothyroidism and brain developmental players. Thyroid Research J. 8(2), 1-12.

[12] Ahmed, R.G., 2015c. Editorials and Commentary: Maternofetal thyroid action and brain development. J. of Advances in Biology; 7(1), 1207-1213.

[13] Ahmed, R.G., 2016a. Gestational dexamethasone alters fetal neuroendocrine axis. Toxicology Letters, 258, 46-54.

[14] Ahmed, R.G., 2016b. Neonatal polychlorinated biphenyls-induced endocrine dysfunction. Ann. Thyroid. Res. 2 (1), 34-35.

[15] Ahmed, R.G., 2016c. Maternal iodine deficiency and brain disorders. Endocrinol Metab Syndr.5, 223. http://dx.doi. org/10.4172/ 2161-1017.1000223.

[16] Ahmed, R.G., 2016d. Maternal bisphenol A alters fetal endocrine system: Thyroid adipokine dysfunction. Food Chem. Toxicology, 95, 168-174.

[17] Ahmed, R.G., 2017a. Developmental thyroid diseases and GABAergic dysfunction. EC Neurology 8.1, 02-04.

[18] Ahmed, R.G., 2017b. Hyperthyroidism and developmental dysfunction. Arch Med. 9, 4.

[19] Ahmed, R.G., 2017c. Anti-thyroid drugs may be at higher risk for perinatal thyroid disease. EC Pharmacology and Toxicology 4.4, 140-142.

[20] Ahmed, R.G., 2017d. Perinatal hypothyroidism and cytoskeleton dysfunction. Endocrinol Metab Syndr 6, 271.doi:10.4172/2161-1017. 1000271

[21] Ahmed, R.G., 2017e.Developmental thyroid diseases and monoaminergic dysfunction. Advances in Applied Science Research 8(3), 01-10.

[22] Ahmed, R.G., 2017f.Hypothyroidism and brain development. J. Anim Res Nutr.2 (2), 13.

[23] Ahmed, R.G., 2017g. Antiepileptic drugs and developmental neuroendocrine dysfunction: Every why has A Wherefore. Arch Med 9(6), 2.

[24] Ahmed, R.G., 2017h. Gestational prooxidantantioxidant imbalance may be at higher risk for postpartum thyroid disease. Endocrinol Metab Syndr 6, 279. doi:10.4172/2161-1017.1000279.

[25] Ahmed, R.G., 2017i. Synergistic actions of thyroid-adipokines axis during development. Endocrinol Metab Syndr 6, 280.doi:10.4172/ 2161-1017.1000280.

[26] Ahmed, R.G., 2017j. Thyroid-insulin dysfunction during development. International Journal of Research Studies in Zoology 3(4), 73-75. DOI: http://dx.doi.org/10.20431/2454941X.0304010.

[27] Ahmed, R.G., 2017k. Developmental thyroid diseases and cholinergic imbalance. International Journal of Research Studies in Zoology 3(4), 70-72. DOI: http://dx.doi.org/ 10.20431/2454941X.0304009.

[28] Ahmed, R.G., 20171. Thyroid diseases and developmental adenosinergic imbalance. Int $\mathbf{J}$ ClinEndocrinol 1(2), 053-055.

[29] Ahmed, R.G., 2017m.Maternal anticancer drugs and fetal neuroendocrine dysfunction in 
experimental animals. Endocrinol Metab Syndr 6, 281.doi:10.4172/2161-1017.1000281.

[30] Ahmed, R.G., 2017n. Letter: Gestational dexamethasone may be at higher risk for thyroid disease developing peripartum. Open Journal of Biomedical \& Life Sciences (Ojbili) 3(2), 01-06.

[31] Ahmed, R.G., 2017o.Deiodinases and developmental hypothyroidism. EC Nutrition $11.5,183-185$.

[32] Ahmed, R.G., 2017p. Maternofetal thyroid hormones and risk of diabetes. Int. J. of Res. Studies in Medical and Health Sciences 2(10), 18-21.

[33] Ahmed, R.G., 2017r.Association between hypothyroidism and renal dysfunctions. International Journal of Research Studies in Medical and Health Sciences 2(11), 1-4.

[34] Ahmed, R.G., 2017s.Maternal hypothyroidism and lung dysfunction. International Journal of Research Studies in Medical and Health Sciences 2(11), 8-11.

[35] Ahmed, R.G., 2017t.Endocrine disruptors; possible mechanisms for inducing developmental disorders. International journal of basic science in medicine (IJBSM) 2(4), $157-160$.

[36] Ahmed, R.G., 2017u. Maternal thyroid hormones trajectories and neonatal behavioral disorders. ARC Journal of Diabetes and Endocrinology 3(2), 18-21.

[37] Ahmed, R.G., 2017v. Maternal thyroid dysfunction and neonatal cardiac disorders. Insights Biol Med. 1, 092-096.

[38] Ahmed, R.G., 2018a. Maternal hypothyroidism and neonatal testicular dysfunction. International Journal of Research Studies in Medical and Health Sciences 3(1), 8-12.

[39] Ahmed, R.G., 2018b. Maternal hypothyroidism and neonatal depression: Current perspective. International Journal of Research Studies in Zoology 4(1), 6-10. DOI: http://dx.doi.org/10.2 0431/2454-941X.0401002.

[40] Ahmed, R.G., 2018c. Non-genomic actions of thyroid hormones during development. App ClinPharmacolToxicol: ACPT-108. DOI: 10.2 9011/ACPT-109. 100008.

[41] Ahmed, R.G., 2018d. Maternal thyroid function and placental hemodynamics. ARC Journal of Animal and Veterinary Sciences 4(1), 9-13. DOI: http://dx.doi.org/10.20431/2455-2518.04 01002.

[42] Ahmed, R.G., 2018e.Interactions between thyroid and growth factors during development. ARC Journal of Diabetes and Endocrinology 4(1), 14. DOI: http://dx.doi.org/10.20431/2455-5983. 0401001.

[43] Ahmed, R.G., 2018f. Maternal thyroid hormones and neonatal appetite. ARC Journal of Nutrition and Growth 4(1), 18-22. DOI: http://dx.doi.org/10.20431/2455-2550.0401005.

[44] Ahmed, R.G., 2018g. Genomic actions of thyroid hormones during development. ARC Journal of Diabetes and Endocrinology 4(1), 58. DOI: http://dx.doi.org/10.20431/2455-59 83. 0401002 .

[45] Ahmed, R.G., 2018h. Dysfunction of maternal thyroid hormones and psychiatric symptoms. American Research Journal of Endocrinology. 2(1), 1-6.

[46] Ahmed, R.G., 2018i. Is there a connection between maternal hypothyroidism and developing autism spectrum disorders? ARC Journal of Neuroscience 3(1), 5-8. DOI: http://dx.doi.org/ 10.20431/2456-057X.0301002.

[47] Ahmed, R.G., 2018j.Maternal thyroid dysfunctions and neonatal bone mal development. American Research Journal of Endocrinology (in press) $\mathrm{xx}-\mathrm{xxx}$.

[48] Ahmed, R.G., 2018k. Maternal thyroid disorders and risk of neonatal seizure: Current perspective. ARC Journal of Neuroscience 3(1), 21-25. DOI: http://dx.doi.org/10.20431/2456057X.0301004

[49] Ahmed, R.G., 20181. Gestational dioxin acts as developing neuroendocrine-disruptor. EC Pharmacology and Toxicology 6.3, 96-100.

[50] Ahmed, R.G., 2018m.Maternal thyroid dysfunction and risk of neonatal stroke. ARC Journal of Animal and Veterinary Sciences 4(1), 22-26. DOI: http://dx.doi.org/10.20431/ 2455-2518.0401004

[51] Ahmed, R.G., 2018n. Maternal thyroid disorders and developing skin dysfunctions. ARC Journal of Dermatology 3(1), 13-17. DOI: http://dx.doi.org/10.20431/2456-0022.0301005

[52] Ahmed, R.G., 2018o. Maternal hypothyroidismmilk ejections: What is the link? ARC Journal of Nutrition and Growth 4(1), 29-33. DOI: http://dx.doi.org/10.20431/ 2455-2550.0401007

[53] Ahmed, R.G., 2018p. Does maternal antepartum hypothyroidism cause fetal and neonatal hyponatremia? ARC Journal of Diabetes and Endocrinology 4(1), xx-Xxx. DOI: http://dx.doi.org/10.20431/2455-5983.0401004

[54] Ahmed, R.G., 2018q. Maternal hypothyroidism and rheumatoid arthritis. International Journal of Research Studies in Medical and Health Sciences Volume 3(2), 1-5.

[55] Ahmed, R.G., 2018r. Developmental thyroid and skeletal muscle dysfunction.ARC Journal of Diabetes and Endocrinology 4(1), xx-xxx. DOI: http://dx.doi.org/10.20431/2455-5983. 04 01003

[56] Ahmed, R.G., Abdel-Latif, M., Ahmed F., 2015a.Protective effects of GM-CSF in experimental neonatal hypothyroidism. International Immunopharmacology 29, 538-543. 
[57] Ahmed, R.G., Abdel-Latif, M., Mahdi, E., ElNesr, K., 2015b. Immune stimulation improves endocrine and neural fetal outcomes in a model of maternofetal thyrotoxicosis. Int. Immuno pharmacol. 29, 714-721.

[58] Ahmed, R.G., Davis, P.J., Davis, F.B., De Vito, P., Farias, R.N., Luly, P., Pedersen, J.Z., Incerpi, S., 2013a. Nongenomic actions of thyroid hormones: from basic research to clinical applications. An update. Immunology, Endocrine \& Metabolic Agents in Medicinal Chemistry, 13(1), 46-59.

[59] Ahmed, R.G., El-Gareib, A.W. 2014.Lactating PTU exposure: I- Alters thyroid-neural axis in neonatal cerebellum. Eur. J. of Biol. and Medical Sci. Res. 2(1), 1-16.

[60] Ahmed, R.G., El-Gareib, A.W., 2017.Maternal carbamazepine alters fetal neuroendocrinecytokines axis. Toxicology 382, 59-66.

[61] Ahmed, R.G., El-Gareib, A.W., Incerpi, S., 2014. Lactating PTU exposure: II- Alters thyroid-axis and prooxidant-antioxidant balance in neonatal cerebellum. Int. Res. J. of Natural Sciences 2(1), 1-20.

[62] Ahmed, R.G.,El-Gareib, A.W., Shaker, H.M., 2018a.Gestational 3,3',4,4',5-pentachlorobiphenyl (PCB 126) exposure disrupts fetoplacental unit: Fetal thyroid-cytokines dysfunction. Life Sciences 192, 213-220.

[63] Ahmed, R.G., Incerpi, S., 2013. Gestational doxorubicin alters fetal thyroid-brain axis. Int. J. Devl. Neuroscience 31, 96-104.

[64] Ahmed, R.G., Incerpi, S., Ahmed, F., Gaber, A., 2013b. The developmental and physiological interactions between free radicals and antioxidant: Effect of environmental pollutants. J. of Natural Sci. Res. 3(13), 74-110.

[65] Ahmed, R.G.,Walaa G.H., Asmaa F.S., 2018b.Suppressive effects of neonatal bisphenol A on the neuroendocrine system. Toxicology and Industrial Health Journal (in press).

[66] Bailey, T., 2010. Auditory pathways and processes: Implications forneuropsychological assessment and diagnosis of children andadolescents. Child Neuropsychol 16, 521 - 48.

[67] Bellis, T.J., 2003. Assessment and management of central auditory processing disorders in the educational setting from science to practice (2nd ed.). San Diego, CA: Plural Publishing.

[68] Bouchard, M., de Caprona, D., Busslinger, M., $\mathrm{Xu}$, P., Fritzsch, B., 2010.Pax 2 andPax 8 cooperate in mouse inner ear morphogenesis and innervation.BMC Dev Biol. 10, 89.

[69] Candelotti, E., De Vito, P., Ahmed, R.G., Luly, P., Davis, P.J., Pedersen, J.Z., Lin, H-Y., Incerpi, I., 2015. Thyroid hormones crosstalk with growth factors: Old facts and new hypotheses. Immun., Endoc. \& Metab. Agents in Med. Chem., 15, 71-85.
[70] Cordas, E.A., Ng, L., Hernandez, A., Kaneshige, M., Cheng, S.Y., Forrest, D., 2012.Thyroid hormone receptors control developmental maturation of the middle ear and the size of the ossicular bones. Endocrinology $153,1548-60$.

[71] Crofton, K.M., 2004. Developmental disruption of thyroid hormone: Correlations with hearing dysfunction in rats. Risk Analysis 24(.6), 1665-71.

[72] Dayal, D., Hansdak, N., Vir, D., Gupta, A., Bakshi, J., 2016. Hearing impairment in children with permanent congenital hypothyroidism: Data from Northwest India. Thyroid Res Pract. 13, 67-70.

[73] Dayal, D., Prasad, R., 2015. Congenital hypothyroidism: Current perspectives. Res Rep EndocrDisord 5, 91-102.

[74] De Vito, P., Candelotti, E., Ahmed, R.G., Luly, P., Davis, P.J., Incerpi, S., Pedersen, J.Z., 2015.Role of thyroid hormones in insulin resistance and diabetes. Immun., Endoc. \& Metab. Agents in Med. Chem., 15, 86-93.

[75] El-bakry, A.M., El-Ghareeb, A.W.,Ahmed, R.G., 2010.Comparative study of the effects of experimentally-induced hypothyroidism and hyperthyroidism in some brain regions in albino rats. Int. J. Dev. Neurosci. 28, 371-389.

[76] El-Ghareeb, A.A., El-Bakry, A.M., Ahmed, R.G., Gaber, A., 2016.Effects of zinc supplementation in neonatal hypothyroidism and cerebellar distortion induced by maternal carbimazole. Asian Journal of Applied Sciences 4(04), 1030-1040.

[77] Incerpi, S., Hsieh, M-T., Lin, H-Y., Cheng, GY., De Vito, P., Fiore, A.M., Ahmed, R.G., Salvia, R., Candelotti, E., Leone, S., Luly, P., Pedersen, J.Z., Davis, F.B., Davis, P.J., 2014. Thyroid hormone inhibition in L6 myoblasts of IGF-I-mediated glucose uptake and proliferation: new roles for integrin $\alpha v \beta 3$. Am. J. Physiol. Cell Physiol. 307, C150-C161.

[78] Knipper, M., Zinn, C., Maier, H., Praetorius, M., Rohbock, K.,Köpschall, I., Zimmermann, U., 2000. Thyroid hormone deficiency before the onset of hearing causes irreversible damage to peripheral and central auditory systems. Journal of Neurophysiology, 83(5), 3101-3112.

[79] Musiek, F.E., Gollegely, M.K., 1985. ABR in eighth nerve andlow brainstem lesions. In JT Jacobsen, editor. The auditory brainstem response (pp. 181- 202). SandDiego: The College-Hill Press.

[80] Ng, L., Goodyear, R.J., Woods, C.A., Schneider, M.J.,Diamond, E., Richardson, G.P., Kelley, M.W., Germain,D.L., Galton, V.A., Forrest, D., 2004. Hearing loss and retarded cochlear development in mice lacking type 2iodothyronine deiodinase. Proceedings from the National Academy of Sciences of the United States of America, 101(10), 3474-3479. 
[81] Oliveira de Andrade, C.L., Machado, G.C., Fernandes, L.C., de Albuquerque, J.M., Casaise-Silva, L.L., Ramos, H.E., Alves, C.A.D., 2017. Mechanisms involved in hearing disorders of thyroid ontogeny: a literature review. Arch Endocrinol Metab. 61(5), 501-50 5.

[82] Over cash, R.T., Marc-Aurele, K.L., Hull, A.D., Ramos, G.A., 2016. Maternal iodine exposure: A case of fetal goiter and neonatal hearing loss. Pediatrics 137(4), e20153722.

[83] Prabhu, S.R., Mahadevan, S., Jagadeesh, S., Suresh, S., 2015. Congenital Hypothyroidism: Recent Indian data. Indian J Endocrinol Metab.19, 436-7.

[84] Santos, K.T., Dias, N.H., Mazeto, G.M., Carvalho, R., Lapate, R.L., Martins, R.H., 2010.Audiologic evaluation in patients with acquired hypothyroidism. Brazilian Journal of Otorhinolaryngology, 76(4), 478-484.

[85] Smith, R.J., Bale, J.F., White, K.R., 2005. Sensorineural hearing loss in children. Lancet 365, 879-90.

[86] Su, P-Y., Huang, K., Hao, J-H., Xu, Y-Q., Yan, S-Q., Li, T., 2011. Maternal thyroid function in the first twenty weeks of pregnancy and subsequent fetal andinfant development: A prospective population-based cohort study in
China. J Clin Endocrinol Metab. 96(10), 32343241.

[87] Van Herck, S.L.J., Geysens, S., Bald, E., Chwatko, G., Delezie, E., Dianati, E., Ahmed, R.G., Darras, V.M., 2013.Maternal transfer of methimazole and effects on thyroid hormone availability in embryonic tissues. Endocrinol. 218, 105-115.

[88] Wasserman, E.E., Nelson, K., Rose, N.R., Eaton, W., Pillion, J.P., Seaberg, E., Talor, M.V., Burek, L., Duggan, A., Yolken, R.H., 2008. Maternal thyroid auto antibodies during the third trimester and hearing deficits in children: An epidemiologic assessment. Am J Epidemiol. 167. 701-710.

[89] Wasserman, E.E., Pillion, J.P., Duggan, A., Nelson, K., Rohde, C., Seaberg, E.C., Talor, M.V., Yolken, R.H., Rose, N.R., 2012. Childhood IQ, hearing loss, and maternal thyroid autoimmunity in the Baltimore Collaborative Perinatal Project. Pediatric Res. 72(5), 525-30.

[90] Weber, G., Rabbiosi, S., Zamproni, I., Fugazzola, L., 2013. Genetic defects of hydrogen peroxide generation in the thyroid gland. J Endocrinal Invest 36, 261-6.

Citation: Ahmed R.G. Maternal Hypothyroidism and Developing Hearing Loss. ARC Journal of Diabetes and Endocrinology. 2018; 4(2):6-10. doi:dx.doi.org/10.20431/2455-5983.0402002.

Copyright: (C) 2018 Authors. This is an open-access article distributed under the terms of the Creative Commons Attribution License, which permits unrestricted use, distribution, and reproduction in any medium, provided the original author and source are credited. 